\title{
ESTIMATIVA DE PARÂMETROS ELÁSTICOS DE MEIOS ANISOTRÓPICOS
}

\author{
Ellen de Nazaré Souza Gomes \\ Orientador: Dr. João dos Santos Protázio (UFPA) \\ 111 p. - Tese (Doutorado) - Defesa 14.01.2004
}

\begin{abstract}
RESUMO. As medidas de amplitude, polarização e vagarosidade contem informações sobre o meio onde a propagação de onda ocorre. Esta tese investiga esses dados com objetivo de estimar as propriedades elásticas deste meio. Coeficientes de reflexão podem ser estimados das amplitudes dos dados e dependem de forma não linear dos contrastes dos parâmetros elásticos e do contraste de densidade entre os meios separados por uma interface. Quando o contraste de impedância é fraco, as aproximações lineares para a refletividade qP são mais convenientes para inversão da densidade e dos parâmetros elásticos usando as análises de amplitude versus ângulo de incidência (AVO) e amplitude versus a direção do plano de incidência (AVD). Escrevendo as equações de Zoepprittz de forma separada nos permite escrever uma solução destas equações em termos das matrizes de impedância e polarização. Usando esta solução são determinadas aproximações lineares para a refletividade da onda qP considerando fraco contraste de impedância, fraca anisotropia mas com classe de simetria de arbitrária. As linearizações são avaliadas para diferentes geometrias de aquisição e várias escolhas do meio de referência. Estas aproximações apresentam bom desempenho comparado com o valor exato do coeficiente de reflexão da onda qP e de suas ondas convertidas para incidências de até $30^{\circ}$ e meios que obedecem à hipótese de fraca anisotropia. Um conjunto de fraturas orientado é representado efetivamente por um meio transversalmente isotrópico (TI), as aproximações lineares da refletividade da onda qP podem ser usadas para estimar a orientação de fratura. Partindo deste pressuposto este problema consiste em estimar a orientação do eixo de simetria a partir de dados de refletividade de onda qP. Este trabalho mostra que são necessários múltiplos azimutes e múltiplas incidências para se obter uma estimativa estável. Também é mostrado que apenas os coeficientes das ondas qS e qT são sensíveis ao mergulho da fratura. Foi investigada a estimativa da anisotropia local através de dados de VSP multiazimutal dos vetores de polarização e vagarosidade. Foram usadas medidas da componente vertical do vetor de vagarosidade e o vetor de polarização de ondas qP diretas e refletidas. 0 esquema de inversão é validado através de exemplos sintéticos considerando diferentes escolhas do vetor normal à frente de onda no meio de referência, meios de referências e geometria de aquisição. Esta análise mostra que somente um subgrupo dos parâmetros elástico pode ser estimado. Uma importante aplicação desta metodologia é o seu potencial para a determinação de classes de anisotropia. A aplicação desta metodologia aos dados do mar de Java mostra que os modelos isotrópicos e TIV são inadequados para 0 ajuste desses dados.
\end{abstract}

ABSTRACT. Amplitude, polarization and the slowness vector measurements carry information about the medium where wave propagation occurs. This thesis investigates these data aiming at the recovery of elastic properties in anisotropic media. Reflection coefficients can be estimated from amplitude data and depend nonlinearly on elastic and density contrasts across an interface. When the impedance contrast is weak, the linear approximations for the qP reflectivity are more convenient for inversion of density and elastic parameters using analysis of amplitude versus the angle of incidence (AVO) and amplitude versus the direction of the incidence plane (AVD). Partitioning the linear system defined by Zoepprittz equations allows one to write the solution of these equations in terms of impedance and polarization matrices. Using this solution, linear approximations for the qP reflectivity are derived for weak impedance contrasts and arbitrary symmetry classes of anisotropy. The linear approximations are evaluated for different acquisition geometries and choice of the reference medium. The approximations for the reflection coefficients of the reflected $\mathrm{qP}$ and the converted waves are in good agreement with the exact solution for incidence angles up to $30^{\circ}$ for media that satisfy the weak impedance assumption. If a single oriented set of fractures is represented by a transversely isotropic effective medium, the linear approximations for qP reflectivity can be used to estimate the fractures orientation. Under these assumptions this problem is reframed as the estimation of the symmetry axis orientation from qP reflectivity data. This work shows the requirement of multiple components and multiple azimuthal data and quantifies the minimum amount of data for stable estimation. Also it is shown that the reflection coefficients of converted waves qS and qT only are sensitive to fractures dip. The inversion of polarization and slowness from multiazimutal VSP data are investigated for the estimation of local anisotropy. We use measurements of the vertical component of the slowness vector and the qP polarization data of direct and reflected waves. The inversion algorithm is validated in synthetic data sets for different choices of the wave front normal, reference medium and acquisition geometries. This analysis shows that only a subset of elastic parameters is recovered. An important application of this approach is its potential to determine the class of anisotropy. The application of this methodology to the Java Sea data set shows that isotropy and transversely isotropic models are inadequate to fit the data. 